\title{
The Concept of Cultural Diversity as a Base for Revitalization Planning
}

\author{
Anna Szewczyk-Świątek, Cracow University of Technology
}

\begin{abstract}
This article attempts to systematize grassroots revitalization plans that shape space, based on the affirmation of cultural diversity. Prototyping is characterized - the method for dynamic development of space, which leads to the creation of carnivalesqued sites evolving under vigilance of the new genius loci. Selected examples of implementation that can determine the pattern of planning for more democratic space in the future are presented.
\end{abstract}

Keywords - Bottom-up revitalization, cultural diversity, participation, prototyping of space.

Though this be madness, yet there's method in't. Shakespeare, Hamlet

Globalization and commercialization involve the homogenization of space resulting from copying places. European countries are becoming more ethnically diversified, while more and more is being said about the failure of the multikulti policy (at the turn of 2010 and 2011,A. Merkel, D. Cameron and N. Sarkozy made a clear statement on this matter). With the agreement of the existence of different societies next to each other, there was seldom an idea of building the space for integration. Despite the intentional making of places characteristic for other cultures (thematisation), there is no place for looking for the collective in what is differently articulated. The process of exploring an uneasy consensus has clearly emerged in the recent years on brownfields, abandoned sites, where groups with different cultural characteristics (e.g. hierarchy of values, work style) aspire for the same space. The article attempts to identify the characteristics of the revitalization process aimed at the creation of the space of agreement and cultural diversity.

\section{Mad Sabotage of Rent}

The multicultural environment is associated with economic growth, the development of production [1] and creative planning ("proactively inclusive" attitude of the community in relation to differences provides a creative city [2]). Strategic plans, however, support only a certain type of diversity in architecture a picturesque and homogenized one, often rejecting experimental or vernacular forms. Ruins of brownfields are adapted, becoming the icons of revitalization, important for branding and gaining value. These investments, however, often do not solve the real problems - according to Peck, the idea of creative planning is popular not because it is effective but because it can be transposed to the neoliberal plans, branding them into creative ones [3]. Moreover, they are the way to support and favor the wealthy and "creative" carrying of a burden of economic and/ or cultural gentrification (for example, the institutionalization of culture). Increasingly locally produced, symbolic value is used to generate profit and capital appreciates distinctive local initiatives (...) discord the homogeneity of the (...) product [4, 154]. Local activities in common areas are an important factor of the value of investments, at the times of capitalism not based on private property $[5,55]$. Harvey sees hope for breaking the development of trade based on symbolic values (authenticity, history, culture, collective memory) in mobilization of opposing to these artists who created local successes [4, 157]. Pasquinelli postulates a sabotage of rent, which is intentional "creative deconstruction" of a purely fictional production of values, the game of deconstruction creation which gives the opportunity to take over the production chain [5, 59]. Novy and Colomb, [6] as the first steps towards building "spaces of hope", describe instances of "creative" of Berlin and Hamburg against plans based on development based on creative industries (Mediaspree) and services (Gängeviertel). Significantly, the opponents were the target group for development plans, against which they unite. The top-down appropriation of previously gained rent by authorities met firm resistance, expressing a creative policy gap namely differently defined principles of the essentials of creative city theory. While the authorities consider creativity primarily in relation to the economic vitality, the people linked it with the quality of life, as a result of the diversity and richness of social and cultural relations [7]. Resistance was expressed not only by demonstrations and occupation movements but also by the creation and maintenance of architectural artifacts, which are an expression of the collective and diverse - mad sabotage. Although these actions "should not succeed", they produce the effect which initiators themselves refer to as a "miracle" [8]. It turned out that the attitude of the authorities has changed - instead of simply [acting] as arbiters of taste and value, (...) are more likely to be involved in (...) development of cultural forms and cultural participation [9]. Conspicuous is the uncertainty of being of bottom-up projects which are too often forced to negotiate the terms of use of municipal property, and have to resist and deal with the threat of losing the adapted place It should be noted that the problem of struggle against the threat of eviction and shortterm rental periods, an uncertain future despite being successful is common among people who care (e.g. YAAM, or Wagenhallen Berlin, Stuttgart).

\section{The New Genius Loci}

Moving the focus from the aesthetic values to the values attached to cultural diversity is essential for promoting the idea of bottom-up planned spaces. The "miracle" of their creation and survival is taken out from the critical approach to beauty.

Experiments have shown that the discovery of beauty, historical value or authenticity is often the cause of the gentrification process and is responsible for adverse changes in the districts. Boltanski and Chiapello [10] suggest that a new spirit of capitalism is based 


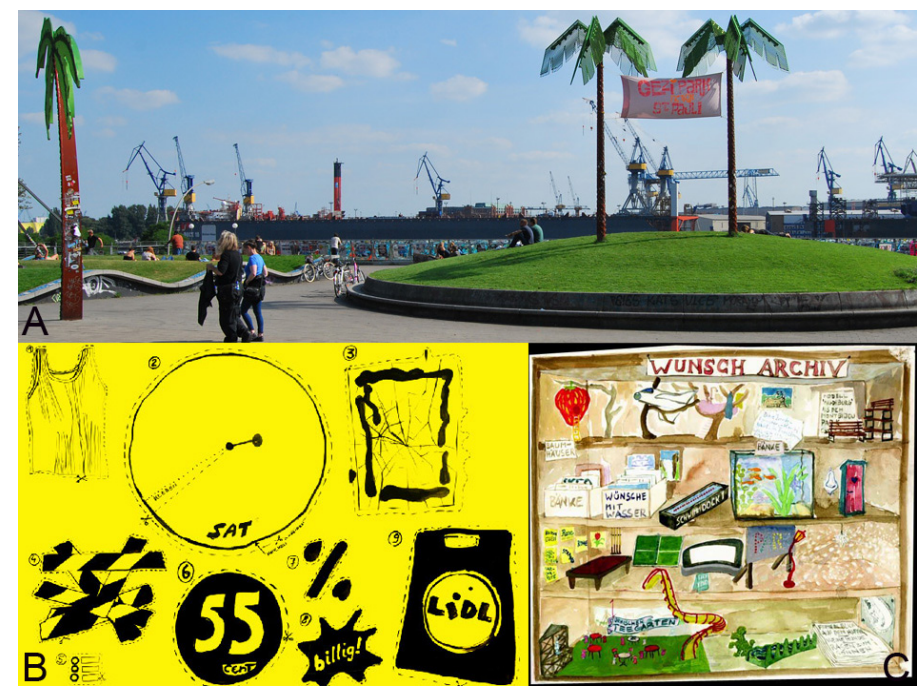

Fig. 1. Park Fiction, Hamburg. A: Completed park (between the palms support banner for Gezi Park); B: Anti-gentrification Kit; C: "Manufactured Dreams" [18].

on the suggestion that the cost of the product is attributed, to a large extent, to its sentimental value and the commercialization of critical attitudes towards capitalism per se. Genius loci set of properties that fit a specific part of the environment (...) unique quality. (...) Attribute including the identity of the place (...) meanings derived from past events and the current situation [11] - as part of the architectural - axiological discourse, so much loved (by its indefiniteness?) by many architects, is increasingly and deliberately sabotaged in the management and development of brownfields by the bottom-up participatory planning practices. A new spirit energy is not apparent from the history, quality, individuality of the place but rather from criticizing them - as they are limits for diversity and experimental creation. The new genius loci - rejects [self] delighting taste $[12,25]$ to allow the autonomous experiment to exist and requires the recipient to resign from the popular aesthetic habits. The experience of scandal - demonstration of beauty or history profanation, is planned to lead to an aesthetic experience, cause an intellectual and emotional stir, leading to the question - what is important for today's constructed sites and their future.

As the value of the site and the building substance are being questioned (their aesthetics, authenticity, relevance), the development can proceed in the direction of increasing entropy of the system or damaging the new spirit of the place and aestheticisation. Creating a new spirit of the place is thus consistent with the fictional creation of value postulated by Pasquinelliego [5], making it possible to engage in a "game for space" under more democratic conditions. Attempts at destroying the spirit and aestheticisation result in protests being considered equal with the devastation of the creative work of the involved individuals (common good is directly affected).

\section{Prototyping AND CARnivalesQue}

Examples of creating a new genius loci, referring to the collective imagination, experiences and memories - not necessarily related to the place of their occurrence, are more and more frequent. Artists, architects ("creative"), come out of the role of the target group to become active, enterprising players.
This "game for space" enshrines the difference and diversity and blows the whistle on alienation and enslavement of individuals through top-down arrangement. Assuming that the contemporary struggle can not be accomplished by using historical methods prototyping is in use implying the dynamic and flexible development of appropriated space by the participating users. The result of prototyping is the expression of identities in the urban space. The use of the abandoned spaces, according to Edensor $[13,70]$ is the result of the affective impact of such places combining the geographical sense of belonging with narratives concerning rebellion, anti-colonialism and space. Locally created sites are based on the memories and symbols from different pasts, performing and advertising them by creating an atmosphere of carnival - as it is carnival (next to sport) that is "the most effective advertising" of the various identities [13, 113]. Translating the language of carnival into architecture (carnivalesque as a concept characterized by the literary convention introduced into the discourse by Mikhail Bakhtin - he described it by aiming to transpose the carnival into the literary language through the use of symbols that build an eccentric "world upside down [14]) carnivalesque convention is an aware departure from the architectural homogeneity, historical accuracy and aesthetics.

Creating places through complexity and unpredictability of the forms of expression makes "conquering" them problematic for outside-investors. The style of exception, the manifestation of difference, deliberately closes opportunities for progress beyond the accepted convention. This is not compatible with the beyond-local initiatives, development on the large scale, due to the objective difficulty of reproduction. Importantly, thanks to the presented design convention, places less - or non - attractive become works of relational art [15], which may result in preserving them. Carnivalesque interventions, then, are gaining importance as pre-revitalization projects (for example Gängeviertel quarter in Hamburg may be seen as proof that the resistance based on diversity contributes not only to preserving the fabric of the building, but could result in legal protection - in this case as being listed heritage as a UNESCO heritage site of cultural diversity). Revitalization through the carnivalesque results in an image from the crossing of the forces of deconstruction and popular tastes with preservation and high art. These days when everyone is / should be creative (the feature previously characteristic for artists became a universalized human trait of being fulfilled, through which a man gives an expression of self definition [16]), the architect, instead of being the creator becomes the curator of the carnivalesque notation of space.

\section{Culturally Diversed Architectural Spaces}

Building a space relying on different identities and cultural diversity is the basis for the inclusion of previously passive, voiceless members of the community. Prototyping the area allows them to take the role of "vicarious investors" who take over the duties previously ceded to the authorities, investing in building, matching and making transformation of the place with their work (tangible and intangible). Although the process of experimenting with the space is most frequently a dynamic phase of transition - it can make a significant impact on the next stages of transformation. 
Revitalized spaces distinctive by cultural diversity can be divided into those, which were influenced by either the collective experiences or collective skills.

Organized, collective experiences stood behind the creation of Park Fiction in Hamburg (Fig. 1A). When the St. Pauli district, where more than $50 \%$ of the residents have no German passport [17], was threatened by gentrification, efforts were made to avoid this process. An anti-gentrification kit was created, which postulated using such elements as broken window glass, satellite dishes and mesh available in low-budget shops (Fig. 1B) in order to fictionally reduce the value of the places. The next step was to mobilize the residents to the "collective production of dreams" (Fig. 1C). With drawings and models, they succeeded in saving the plot from commercial development and created the park as suggested by users. The park features, among others, an island with palm trees and a lawn in the shape of a flying carpet - which is the materialization of childhood memories and exotic roots of inhabitants, to which artists and architects surrender. People with different backgrounds and most various life contexts created a space that is a place of constant social activity.

An example of a more aesthetically radical form of land use, referring to the roots and experiences of a multicultural, nomadic society is the YAAM (Young African Art Market) in Berlin. This place is very popular among Berliners, immigrants (mostly from Africa, the Caribbean, Brazil) as well as tourists. Located on the banks of the Spree River, the YAAM is a field for urban sports, music, and cheap restaurants built in "patchwork" style (Fig. 2A). Through the use of pieces of metal, wood, leaves, pet bottles, the space was a bottom-up creation and associated with the places where these materials are considered as usable in construction and have no clearly negative connotations. This is similar to what was done in DOK Gent, where (with less success) attempts were made to involve in the revitalization not only internationally recognized artists, but also beginners and marginalized groups (Fig. 2B). It is worth noting that, despite the use of lower quality materials and durability, spaces of interactions were built, the spaces of equality between the unequal, spaces, which refer to identity, reminiscent of the exotic landscapes, not the stigmatizing poverty.

Collective artistic skills are the foundation of development of such sites as Gängeviertel in Hamburg (Fig. 3). The "Komm in die Gänge" social initiative was launched by a group of artists volunteers, who took over the quarter, opposing its sale and demolition. Due to such an act, the authorities decided to redeem the land from the investor and make it available to the collective for laboratories, workshops and social housing for "those who have a good idea (artistic, social, cultural) and do not have the funds"[8]. The space is supported by charitable work of association members and private donations.

The form of the complex consists of the conglomerate of various art forms that are "stuck" to the historic matter. The borders of architecture are consciously exceeded, certain deeds not considered as worthy of use in the revitalization of historic substance are integrated. Moreover, materials normally allowed only in primitive constructions because of instability or low value are used. The grotesque reality of lower significance, without prestige, is being built.

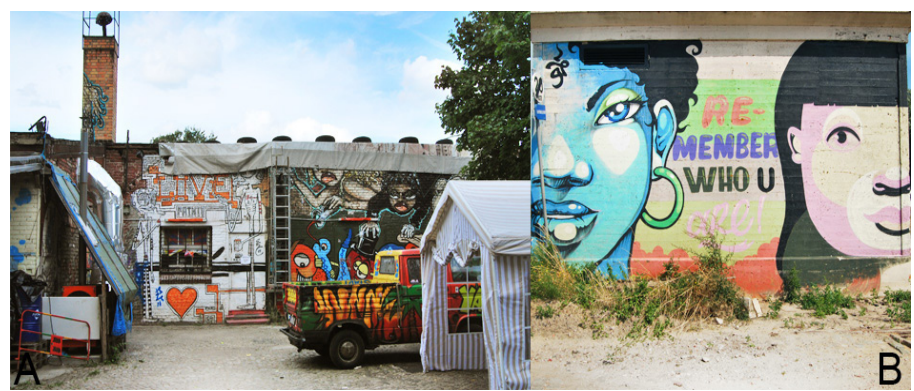

Fig. 2. A: YAAM, Berlin - The built environment as a reconstruction of exotic memories; B: DOK Gent - Encouragement to cultivate diversity [19].

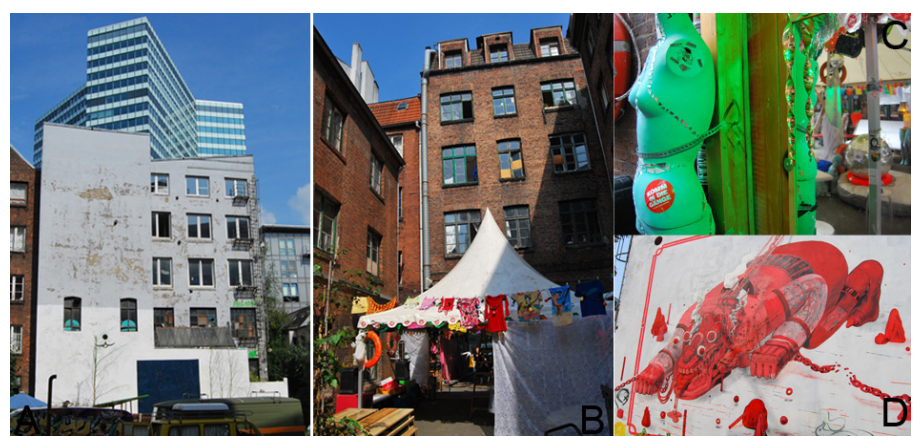

Fig. 3. Gängeviertel, Hamburg. A -External view of the Quarter; B - Quarter interior, C -Transgressive architectural forms; D - The vivid mural in one of the passes [20].

The idea of future revitalization accepting the diversity and evolution of such plans as a basis can be traced back on the example of the construction of the Berlin urban quarter Holzmarkt (en. Wood Market). The history of the project dates back to 2004 and the iconic bar, Bar25 - located on the banks of the Spree River - the "playground for adults" (Fig. 4A). The architecture of the club resulted from the "alpine hut crossed with a saloon from Wild West". The fame of the place did not affect the design, which excelled in building an atmosphere of grotesque.

The closing of the events venue in 2010 did not become the end of the development of aesthetic actions - they are being continued in the new location. Thanks to its popularity, the bar is reborn in an abandoned soap factory on the opposite bank of the river. The postindustrial facility became the seat of club music, galleries, workshops, flea markets, and its activity continues in carnivalesque form (Fig. 4B). Some damages are consciously maintained (ruins, broken windows, "patches"). The architectural body has been incorporated with elements of interior design (furniture, textiles). There is a frequent sight of compositions of disposable products and "garlands" of used clothing, puppets, mannequins and sculptures located in the most unexpected places.

The Holzmarkt development plan draws experience from the successful projects described above. However, a growing scale of investments may be noticed. Invariably, spaces are managed according to the idea of promoting cultural diversity, creativity and sustainability. Such investments brought together a large number of people who seems to be pleased with these ideas and styles. The culmination was the purchase of land from the City (2012), on which the first steps were placed (the bid was highly politicized, which is not surprising because the decision is another confirmation of the failure of the Mediaspree plan [22]. 


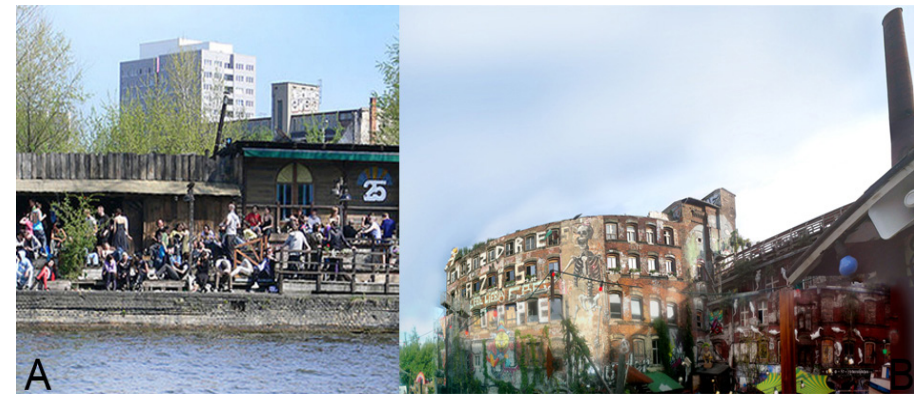

Fig. 4. A: Bar 25, Berlin; B: KaterHolzig, Berlin [21].

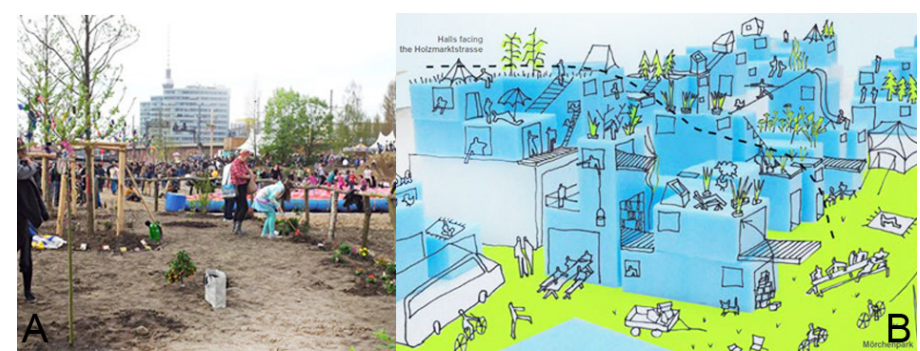

Fig.5. A: Mörchenpark, Berlin - Developing works; B: Holzmarkt, Berlin - The vision of development [23].

Plans are made on the area of Urban Quarter Holzmarkt (18ha): for the residential village composed of customizable and extensible units (constantly changing place, (...) in the process of change [22, 9-11]), club, hotel, restaurant, technology center (Eckwerk) and a large public park (where the first trees and vegetables were planted in 2013 - Fig. 5A). It is important that the development plan emphasizes the use and shaping of space by cultural diversity (Fig. 5B): by different users $[22,11]$, in the process of continuous change [22, 12], drawing on previous experience - history shaped by constant change and creative renewals $[22,24]$.

The described actions affected the metamorphosis of the business models of the participatory projects and indicated the direction of change in the real estate market. These changes include an increase of people's interest in the methods of developing the real estate and urban planning and rolling out new players - entrepreneurial collectives. With these transformations, the Park Fiction could be built (although some elements of the project are still waiting for their time). The project used funds for art projects (not investments) in the urban space. On the other hand, the YAAM is still being threatened and negotiated, despite the support petitions reaching thousands of signatures [24]. The budget of the association does not have the amount needed to purchase the land, but enough to continue the operations and implementations of the programs relating to social cohesion. Gängeviertel and DOK Gent found their opportunity in adopting the "label" of creative ground, important for city branding. This allows the area to be used bearing only the costs associated with the operation. The Holzmarkt Plus cooperative has established a partnership with business (the area was purchased by the Swiss Pension Fund - Abendbrot Foundation and leased for social cooperative Genossenschaft für Urbäne Kreativität eG [22, 15]) to form a model of social - private partnership. Time will tell how these choices affect the development and fulfillment of the objectives of promoting cultural diversity.

\section{CONCLUSIONS}

What After Carnival? Planning Contestation as Planning Itself? On a large scale, today urban projects turn out as at times difficult to implement due to the large number of protests. The top-down plans concerning the various dynamics of community life sharing one territory are rarely considered, preventing the inside integration. Public plans contestation resulting from the lack of proposals taking the cultural diversity into account can be inhibited by the bottom-up planning development and the promotion of prototyping solutions locally. The cultural diversity policy should be based on being rooted in a number of smaller investments that take into account specific needs.

Bottom-up, mad initiatives of excess may be a method of creating valuable common areas, which are under continuous change. Despite experiencing the aesthetic and ideological materialization "of the world as seen through the eyes of a madman", it may occur that "there is a method to this madness" approaching the planning and creating more democratic common places. Gentrification can probably not be completely eliminated, but can be limited by building places that favor community, which many groups can identify with.

Although it is not known how many of these (or similar) places will survive, become form-stable, it can be stated today that "miracles do happen", which allows for an optimistic look into the future to see the over-aesthetic sense of taken actions.

\section{REFERENCES}

1. UNESCO Universal Declaration on Cultural Diversity, Paris 2001, art. 3, 7, 9.

2.. Florida, R. The flight of the creative class: the new global competition for talent, New York: HarperBusiness, 2007. p. 39.

3. Peck, J. Struggling with the Creative Class. International Journal of Urban and Regional Research. [online]. Oxford: Wiley, 2005, vol. 29, Issue 4, pp. 740-770. [cited 24.04.2013.] http://dx.doi.org/10.1111/j.14682427.2005.00620.x

4. Harvey, D. Bunt miast (en. Rebel cities), trans. by Praktyka Teoretyczna. Warszawa: bęc zmiana, 2012. p. 154.

5. Pasquinelli, M. Na ruinach miasta kreatywnego: Berlińska fabryka wiedzy a sabotaż renty (Eng. Beyond the ruins of the creative city: Berlin's factory of culture and the sabotage of rent), trans. by Szadkowski K. In: Ekonomia kultury: Przewodnik Krytyki Politycznej. Warszawa: Wyd. KP, 2010. p. 55.

6. Novy, J., Colomb, C. Struggling for the Right to the (Creative) City in Berlin and Hamburg: New Urban Social Movements, New 'Spaces of Hope'? International Journal of Urban and Regional Research [online]. Oxford: Wiley, 2012, p. 23. [cited 28.03.2013.]. http://dx.doi.org/10.1111/ j.1468-2427.2012.01115.x

7. Borén, T. Young, C. Getting Creative with the 'Creative City'? Towards New Perspectives on Creativity in Urban Policy. International Journal of Urban and Regional Research [online]. Oxford: Blackwell Publishing, 2012 , p. 14. [cited 28.03.2013.]. http://dx.doi.org/10.1111/j.14682427.2012.01132.x

8. Interview with Christine Ebeling (Gängeviertel Association from Hamburg) conducted by author on 22nd of August 2013

9. Pratt, A. Cultural industries and public policy. International Journal of Cultural Policy. [online]. Taylor and Francis, 2005, vol. 11, Issue 1, pp. 31-44. [cited 17.09.2013.]. http://dx.doi.org/10.1080/10286630500067739

10. Boltanski, L., Chiapello, E. New Spirit of Capitalism, trans. by: Eliott, G. London: Verso, 2005. 
11. Lenartowicz, J., K. Słownik psychologii architektury. Kraków: Wydawnictwo PK, 2010. pp. 33-34.

12. Adorno, T. Teoria estetyczna, trans. by Krzemieniowa, K. Warszawa: Wydawnictwo Naukowe PWN, 1994. p. 25.

13. Edendor, T. Tożsamość narodowa, kultura popularna $i$ życie codzienne. (en. National Identity, Popular Culture and Everyday Life), trans. by Sadza, A. Kraków: Wydawnictwo UJ, 2004. p. 70, 113.

14. Bakhtin, M. Problemy poetyki Dostojewskiego, trans. by Modzelewska, N. Warszawa: PIW, 1970. pp. 187-193. A characteristic feature of the carnivalesque images is their ambivalent structure and eccentricity.

15. Kahn, K. Die Prekäre Einheit von Kunst und Leben. In: Mehr als ein Viertel (ed. Gängeviertel e.V.). Berlin: Assoziation A, 2012.pp. 167-172.

16. Zawadzka, A. Przymus kreatywności In: Wieczna Radość: Ekonomia społecznej kreatywności (ed. Sowa, J.). Warszawa: bęc zmiana, 2011. p. 227.

17. Schäfer, Ch. The City is Unwritten [online]. Park Fiction, 2004 [cited 19.09.2013.]. http://park-fiction.net/the-city-is-unwritten-urbanexperiences-and-thoughts-seen-through-park-fiction/

18. A: Photo by Anna Szewczyk, 2013; B: Archiv of Aktionsnetzwerk http:// urbanshit.de/bilder_urbanshit/abwertungskit.jpg [cited 19.09.2013.]. C: Wunsch Archiv of Park Fiction. http://www.nadir.org/nadir/initiativ/ parkfiction/images/2006/10/159.jpg [cited 19.09.2013.].

19. Photos by Anna Szewczyk, 2013.

20. Photos by Anna Szewczyk, 2013.

21. A: Photo by Andreas Praefcke, 2009. http://commons.wikimedia.org/wiki/ File:Berlin_Spree_Bar25_Holzmarktstra\%C3\%9Fe.jpg [cited 19.09.2013.]; B: Photo by Anna Szewczyk, 2013.

22. Holmarkt (ed. Wöhr, S.) [online]. Berlin: Holzmarkt plus eG, 2012. [cited 19.09.2013.]. http://www.holzmarkt.com/seite/public/downloads-en/ Holzmarktbrochure_english.pdf

23. A: PHOTO BY Christian Ott, 2013, http://www.taz.de/uploads/ images/684x342/moehrchenpark.jpg [cited 19.09.2013.]; B: Drawing by carpaneto.schöningh architekten / Hütten \& Paläste Architekten / deadline architekten, 2012. In: [22, 19].

24. YAAM Must Survive! [online]. OpenPetition [cited 19.09.2013.]. https:// www.openpetition.de/petition/online/yaam-must-survive-petition-zurerhaltung-des-yaamgelaendes-am-ostbahnhof

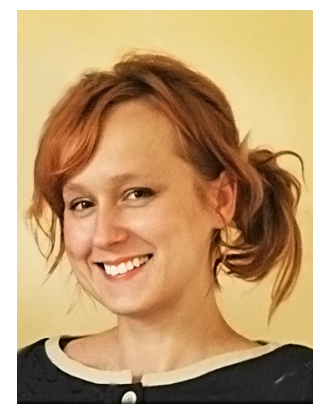

Anna Szewczyk-Świątek (Kraków, 1981) M. Sc. arch. (Cracow University of Technology, 2006).

$\mathrm{PhD}$ student at the Faculty of Architecture, Cracow University of Technology (since 2010).

Certified architect (since 2012) and co-owner of 55Architekci (since 2008). Participated in scientific conferences (e.g. Creative Urbanism, Lviv 2013; Architecture, Education \& Society, Barcelona 2013) and architectural competitions (ie. Buzodrom in Limanowa, $20081^{\text {st }}$ prize with Świątek W., built 2011). Author and co-author of several projects of private and public buildings (i.e. Library in Gołkowice, 2013).

Current and previous research interests: revitalization of postindustrial sites, revitalization by carnivalesque, cultural diversity in architecture.

\section{Contact Data}

Anna Szewczyk-Świątek

Politechnika Krakowska, Wydział Architektury

Address: ul. Podchorążych 1, 30-084 Kraków, Polska

Phone: +48504137254

E-mail: aszwk@poczta.onet.pl 